\title{
EDUCATION CONCERNING HISTORICAL CITIES AS AN EXAMPLE OF AN ORIGINAL CURRICULUM TAUGHT TO STUDENTS OF THE ARCHITECTURE AND SPATIAL MANAGEMENT COURSES
}

\author{
Dominika Kuśnierz-Krupa ${ }^{1}$
}

\begin{abstract}
This article discusses the need for social education - in this case, concerning students of the architecture and spatial management courses - on the matter of the protection of historical cities. In response to this need, the author of the article has formulated two original curricula covering this scope. They are taught at the Cracow University of Technology. The first, as a seminar, is addressed to students of the architecture course and has been named "Protection of historical cities". The second is taught as a spatial management course in the form of design classes and has been named "Legal and social conditions in the protection of the cultural landscape". The need to educate students of architecture and spatial management on the matter of the protection of the cultural landscape of historical cities is necessary due to the potential threat to cultural heritage that is posed by new development projects. Future architects and planners must understand the need to protect historical assets and the value of historical urban layouts and precious works of architecture. Only then will they be able to properly, correctly and responsibly practice their future profession which will include, among other things, the verification of and participation (to a varying degree) in the process of carrying out architectural and urban design projects, often in a historical environment. It should be noted that the protection of cultural heritage, including historical cities, is an important aspect of the functioning of every society, as cultural heritage is an essential factor of the life and conduct of every person. It constitutes the material and spiritual legacy of past generations, as well as the legacy of our time.
\end{abstract}

UDC Classification: 71, DOI: 10.12955/cbup.v7.1404

Keywords: Education, historical city, protection, revaluation

\section{Introduction}

Protecting cultural heritage is an important aspect of the functioning of any society. According to the Polish National Heritage Institute, "it constitutes the material and spiritual legacy of past generations, as well as the legacy of our time. It denotes value - tangible or intangible-handed down by our ancestors and that defines our culture. It includes in it all of the environmental effects resulting from the interaction between humans and their surroundings over the centuries" (National Heritage Institute, 2019). Therefore, its protection is extremely important and, as a result, so is social education, whose goal should be to raise awareness concerning the value of the domestic cultural landscape, historical structures and space. The protection of the cultural landscape, including the cultural heritage of cities, was mentioned in several international documents, including the Charter for the conservation of historic towns and urban areas published by ICOMOS in Washington in 1987, as well as the UNESCO Recommendation on the historic urban landscape, drafted in Paris in 2011. At the same time, numerous scholarly publications discussing the subject of the cultural landscape in its various aspects are written. Their authors point to the protection of the cultural landscape (Kuśnierz-Krupa \& Krupa, 2017), the need to document it (Krupa, 2018) and make it accessible (Kuśnierz-Krupa \& Krupa, 2008), underscoring positive examples of the restoration of both historical buildings (Kuśnierz-Krupa, 2017) and entire urban complexes (Krupa, 2015). When discussing the problem of the cultural landscape which is currently under threat of decay by the uncontrolled expansion of development, we should also consider the precepts of sustainable development (The Sustainable Development Agenda, 2015), which require us to protect and restore cultural heritage so that it will survive and be accessible to future generations.

All of the abovementioned topical problems associated with the protection of cultural heritage result in a need for far-reaching social education concerning the need for protection, but most of all, raising awareness of the value of heritage as a form of global capital that our ancestors have amassed, chiefly among future designers (architects and planners) who are being given a significant mandate of trust and influence over the creation of the space that surrounds us.

\section{The "Protection of historical urban complexes" module}

The "Protection of historical urban complexes" module is aimed at students of the Architecture course who study at the Faculty of Architecture of the Cracow University of Technology. The scope of the module was formulated by the Author of this article in 2014, with the module being added to the curriculum of Master's studies (second tier) a year later, in 2015. Module classes are taught during the second semester of the first year, in the form of seminars with an allotted time of 15 hours.

\footnotetext{
${ }^{1}$ Faculty of Architecture, Cracow University of Technology, Cracow, Poland, dkusnierz-krupa@ pk.edu.pl.
} 
The goal of the module is to educate students on the matter of respecting as well as the need for the restoration and protection of the cultural landscape of cities, providing them knowledge concerning the constitutive elements of historical cities, as well as forms and methods of their protection that are used in Poland and Europe. As a part of the module, students prepare a term project in six-person groups. The subject of the project is one of several tens of small Polish towns of the Lesser Poland or Subcarpathian voivodships e.g. Myślenice (Fig.1), Niepołomice, Wieliczka (Fig.2), Bochnia, Brzesko, Nowy Targ, Lanckorona and others. These towns are centres with a rich history and that still possess a significant body of cultural heritage sites, which are currently facing problems with protecting and restoring them (D. Kuśnierz-Krupa, 2019).
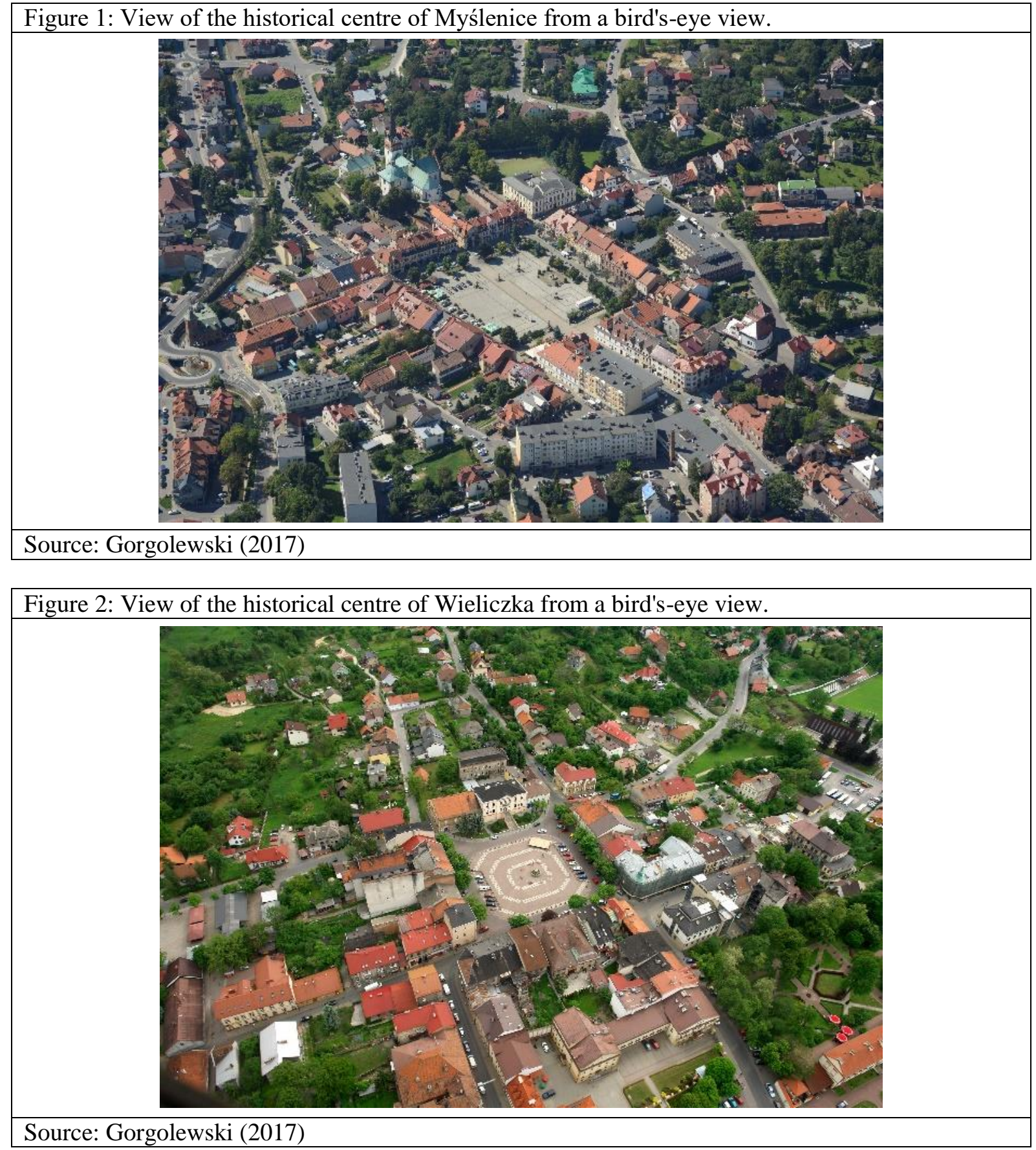

The project that students prepare is composed of three parts. The first part focuses on the history of the selected town. Using literature and all other available sources (e.g. the national archive, museum collections, the archives of local associations), the students are to write a schematic overview of the history of the urban centre and supplement it with archival cartography (historical maps) and iconography (engravings, archival photographs, postcards). This is a very important education stage, as 
well as of the term project, because students gather their first pieces of information about the history of the city, the conditions in which it was established, local traditions and cultural assets.

Upon completing the first part of the project, students start to work on the second part of their task, which pertains to the present and the current condition of the city's cultural heritage assets. They perform field research in the form of on-site visits to sites in the selected city, evaluating its assets and commenting on the state of preservation of its historical buildings and spaces. The photographic documentation that students prepare, along with the plan of the city, on which they mark the photographed and evaluated buildings, is a very important element of this section of the project. Thanks to the previously acquired knowledge about the town's history, the students already know which elements of the city's cultural landscape they should focus on. These are predominantly: the local parish church, the town hall, the market square, the monastery, examples of historical timber and masonry residential architecture, the synagogue, and/or relics of historical industrial buildings. This section makes students aware of which historical buildings still exist in the town and what their current technical condition is.

The final (third) part of the term project is a conclusion of the entire module. As a part of this section, students verify the legal regulations associated with the protection of the town's cultural landscape. They acquaint themselves with the heritage sites registry and the municipal historical sites registry, they analyse the provisions of the town's local spatial development plan in terms of additional indications concerning the protection of cultural heritage. Thanks to these efforts they gain knowledge on the forms of protecting heritage sites listed in the Act on the Protection and Preservation of Historical Monuments of 2003 (with later changes), as well as the manner in which information on this subject can be collected. The third part ends with a presentation of a concept of activating and promoting the selected town with the use of its cultural assets. Here it should be noted that the project focuses on small towns, which are not too wealthy, and therefore suffer from neglect. These towns, apart from problems associated with maintenance and proper restoration and preservation of their bodies of cultural heritage sites are also tackling other issues such as unemployment or slow economic development. Oftentimes it also happens that these towns, despite a rich history and a wealth of heritage sites, are not perceived as historical towns that are worthy of protection or of being familiarised with. This statement applies both to the residents of these towns, as well as potential tourists.

Coming back to the concept that the students present, it should be noted that it is meant to highlight the potential possibilities of procuring funding for the town's protection and restoration.

In conclusion, the "Protection of historical urban complexes" module is primarily meant to sensitise future architects to the problems of protecting the cultural landscape of historical towns, while the project that they prepare is meant to teach them teamwork, perform subject literature and archival collection queries, conduct field research and asset evaluation and, as a result, analyse the collected materials and prepare a comprehensive vision of the development of a historical town with the use of its history, tradition and heritage sites on this basis.

\section{The "Legal and social conditions in the protection of the cultural landscape" module}

The "Legal and social conditions in the protection of the cultural landscape" module is addressed to students of the inter-faculty Spatial Management course taught at the Cracow University of Technology. The content of the module was prepared by the Author of this article in 2017 and it became included in the Master's studies (second tier) curriculum of the course a year later, in 2018. The classes are taught to first-semester first-year students in the form of 15 hours of design classes.

Teaching students about legal regulations and social attitudes associated with the cultural landscape is associated with properly preparing them for future professional work in municipal administration positions or design companies. It appears essential for there to be an element of social education concerning respect for the cultural landscape and its perception as a value here.

As a part of the presented module, students work in two-person groups and prepare a conceptual design proposal associated with the promotion of the cultural landscape of a pre-determined town.

In the current year the town that is being worked on is Skawina. Skawina is a Medieval historical town located around $20 \mathrm{~km}$ to the south-west of Krakow. It was established by a royal charter in 1364 A.D. on the land of three pre-existing villages that had belonged to the monastery of the Benedictine monks in Tyniec (Kuśnierz-Krupa, 2010). A royal castle was located in Skawina, which, during the Middle 
Ages, fulfilled an important role in the state's defensive system created by King Casimir the Great. The parish church of Saints Simon and Judah that has survived to this day is also dated to the period of the town's founding (Kuśnierz-Krupa, 2010).

The town's history has produced a sizeable body of cultural heritage sites, which is primarily composed of: the foundation-period Medieval urban layout, the parish church of Saints Simon and Judah along with its nearby cemetery, the filial church of the Visitation, a synagogue, a nineteenth-century town hall, a train station complex, a building of the historical "Sokół" Gymnastics Association, historical townhouses located around the market square (Fig.3), relics of historical timber buildings, relics of industrial buildings from the end of the nineteenth and the beginning of the twentieth century (Krupa, 2015), as well as numerous historical chapels.

The subject of the project is a conceptual design proposal of a spatial form or several spatial forms that will constitute a symbol in the cultural space of the town (Fig.4). It can have a symbolic dimension but can also be functional. It is meant to promote and shape social education in terms of the popularisation of knowledge about the history of the town and its historical sites. Design work is preceded by predesign studies divided into two stages. The first stage is associated with the students learning the history of the town and its historical sites. The analysis of the legal regulations associated with the statutory protection of the town's heritage sites is an important element of this stage. The second stage of predesign studies is associated with the analysis of the current state of the cultural landscape and is based on on-site visits across Skawina. Based on the collected information, students can make informed decisions concerning what the specific subject of their work will be and why, as well as which of the town's historical structures or groups of such structures should be promoted more, or about which the local community or tourists should be reminded of.

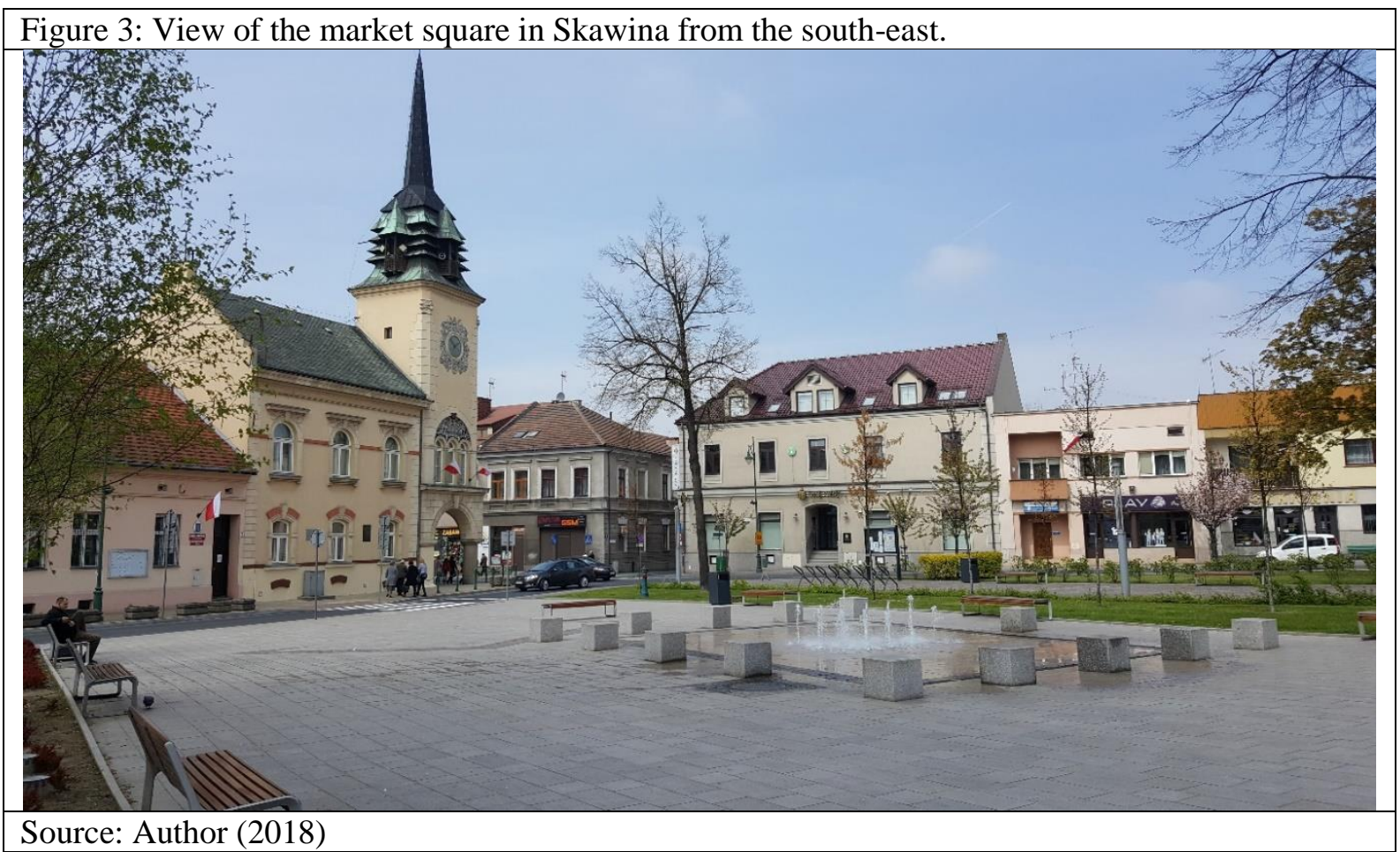

\section{Conclusion}

As a conclusion to the discussion presented above, it should be noted that the problem of the protection of cultural heritage is a society-wide dimension. Designers, both architects and planners, who have a direct influence on buildings and spaces of high cultural value, including existing ones, have an important role to play here. They can exponentially aid the process of their protection and appropriate restoration. It is for this reason that the modules described above must be a component of the curricula of both the architecture and spatial management course. Their goal is to transfer knowledge about the heritage value of the historical city, the principles of the protection of this value, having students understand the need for the protection and restoration of the cultural landscape and the legal regulations 


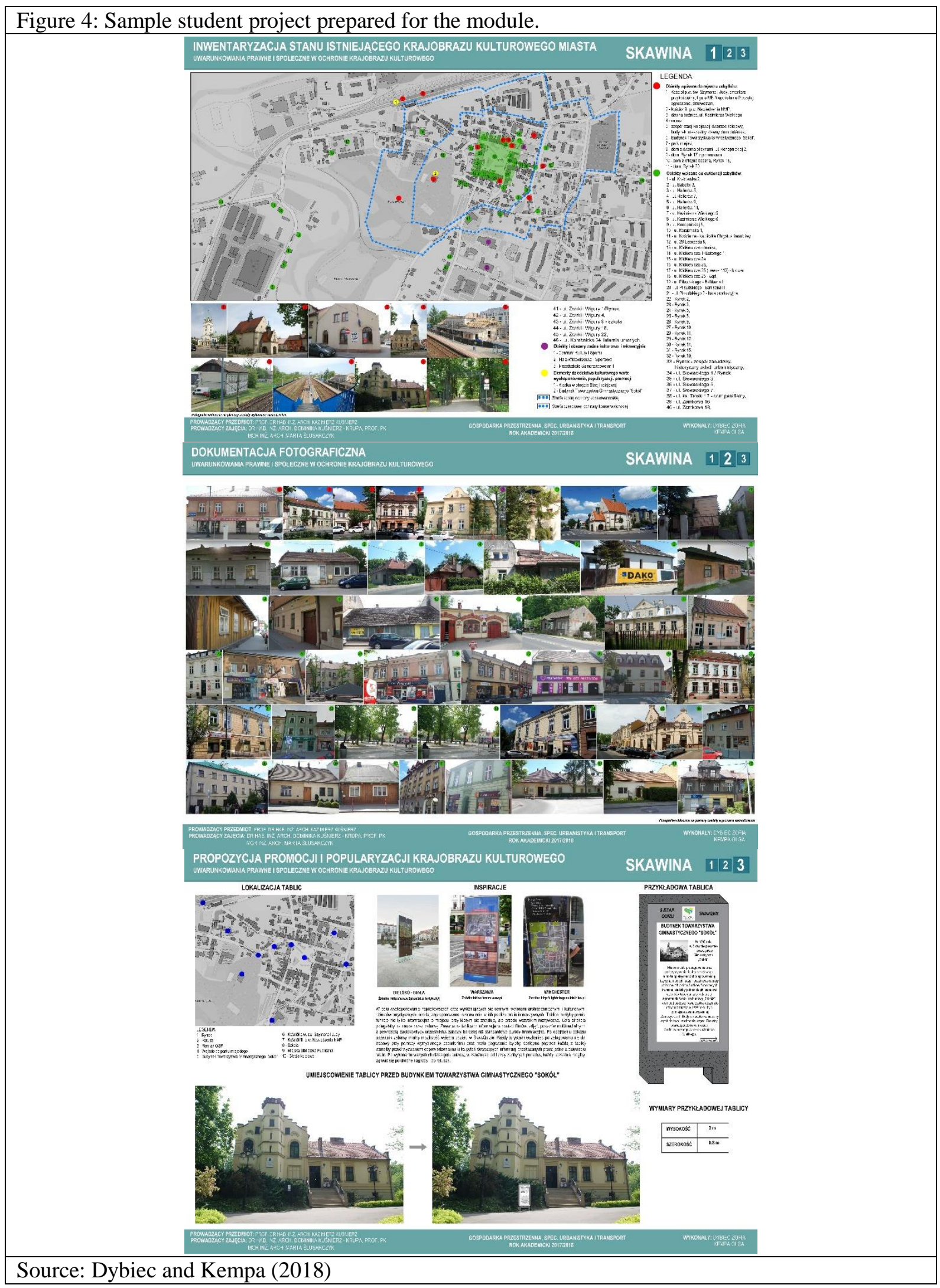

and social attitudes associated with its protection. As a consequence, students learn the procedure associated with design work that is proper for historical buildings that makes it possible to restore and properly protect them.

They also present their own visions associated with the revitalisation of historical cities, as well as of their promotion and protection. These ideas can be used and implemented by the authorities of the 
analysed historical cities. The student projects are planned to also be shared with the local community by, among other things, the organisation of open-air exhibitions. Because of this, the modules gain a broader dimension, one that is linked with the popularisation of cultural heritage outside the university, on the grounds of historical urban centres themselves and among the general population.

\section{References}

National Heritage Institute -NID, (2019), Retrieved from

https://www.nid.pl/pl/Informacje_ogolne/Ochrona_dziedzictwa_kulturowego/, retrieved on: 15.03.2019.

Charter for the conservation of historic towns and urban areas, (1987), Retrieved from

https://www.icomos.org/charters/towns_e.pdf, retrieved on: 15.03.2019.

Recommendation on the historic urban landscape, (2011), Retrieved from

https://whc.unesco.org/uploads/activities/documents/activity-638-98.pdf

Kuśnierz-Krupa D., Krupa M., (2017), Lorsch - Carolingian heritage. Introduction to research on the cultural heritage of the town, Wiadomości Konserwatorskie - Journal of Heritage Conservation (50), 20-29.

Krupa M., (2018), Rabka-Zdrój. Urban-architectonic aspects of cultural Heritage, Wrocław, Kraków, DWE,

Kuśnierz-Krupa D., Krupa M., (2008), New live of medieval churches in Maastricht, Wiadomości Konserwatorskie - Journal of Heritage Conservation, (24), 103-106.

Kuśnierz-Krupa D., Krupa M., (2017), Heppenheim - a model example of well-used cultural potential of a small town, Journal of Civil Engineering, Environment and Architecture, (3/2), 161-180.

Krupa M., (2017), Cultural heritage of small towns in central and western Germany - selected examples, Wiadomości Konserwatorskie - Journal of Heritage Conservation, (52), 27-35.

The Sustainable Development Agenda, (2015), Retrieved from https://www.un.org/sustainabledevelopment/sustainabledevelopment-goals/.

Kuśnierz-Krupa D., (2019), Issue of protecting historic urban layouts of small towns in south-eastern Poland - on selected examples, IOP Conference Series: Materials Science and Engineering, (471), 1-10.

Kuśnierz-Krupa D., (2012), Skawina w średniowieczu, Kraków, PK, Kraków, 31.

Kuśnierz-Krupa D., (2010), The castle Skawina as an example of medieval stronghold founded by King Casimir the Great, Wiadomości Konserwatorskie - Journal of Heritage Conservation, (27), 145-152.

Krupa M., (2015), Architectonic transformations of Skawina at the turn of the 19th and 20th century. Part II - public utility buildings, Wiadomości Konserwatorskie - Journal of Heritage Conservation, (42), 44-53.

Dybiec Z., Kempa O., (2018), Skawina. Student project prepared for the module. 